\title{
Re-Examining the Structure of Firms and the Provision of Finance: The Case for Islamic Partnerships
}

\author{
Shams Osama Haikal ${ }^{1}$ \\ ${ }^{1}$ Institute of Islamic Banking and Finance, International Islamic University Malaysia \\ Correspondence: Shams Osama Haikal, Doha, Qatar. Tel: 974-5517-8763. E-mail: shams.u.haikal@gmail.com
}

Received: August 24, 2019

Accepted: September 10, 2019

Online Published: September 29, 2019

doi:10.5539/ass.v15n10p64

URL: https://doi.org/10.5539/ass.v15n10p64

\begin{abstract}
In the past, Muslims and non-Muslims mainly depended on equity-based financing while debt was an exception, but this whole system was altered with the inception of banks followed by the corporations and the role of partnerships started to shrink. Accordingly, many issues emerged concerning the current financial system, for instance three different banking theories were developed that are based on different understanding of how banks and money function and each lead to different economic and policy implications. Frankly, the new entire system was borrowed from the English law and hence raised doubt about its compliance with Sharì'ah. Accordingly, the study aims to re-examine the structure of corporations, especially the concept of legal personality, and the provision of debt finance under the principles of Islamic law and their effect on the economy as compared to partnerships. The study employed library research, content analysis as well as case study approaches and found that the only correct banking theory that is supported by an empirical evidence is the credit creation theory which states that banks can create money out of nothing. Moreover, after analyzing the concept of legal personality, the concept proved not to be accepted by the classical scholars although the majority of the contemporary scholars insist on its validity. Furthermore, the whole structure was found to contradict some of the main principles of Islamic law. Finally, partnerships were found to be more efficient than the debt-based system in terms of allocating the investable resources and the marginal efficiency of capital.
\end{abstract}

Keywords: partnerships, financial crisis, marginal efficiency of capital, modern corporation, legal personality, banking theories, credit creation, Maqāṣid Al-Sharì'ah

\section{Introduction}

\subsection{Background}

Previously, partnerships which entirely depend on equity were considered the best channel used by Muslim investors and many scholars adopted studies that showed its importance and positive impact on the whole economy. Furthermore, partnerships were the prevalent method for commerce since the prophet time as he (pbuh) and his noble companions (mAbpwt) themselves used to engage in partnerships especially mud̄arabah. (Udovitch, 1970, p. 186). Not exclusive to the Muslim society, partnerships also reached Europe through the so called commenda and societas. Hence many writers were interested to write about the origins of these forms and the majority agreed that they are an extension of the Islamic mud̄arabah and mushārakah respectively (Çizakça, 1996, p. 12). But this equity-based system is no longer prevalent since the whole financial system was altered with the inception of banks which became the main provision of debt financing; their main job is extending loans and collecting fixed returns out of it. Scholars have not yet come to any consensus about how the banks and money are functioning under the banking system, and they have developed three theories where each theory leads to totally different economic and policy implications.

Following this, a new form of business organization started to originate through some gradual legislations made by the English law. This form is called the corporation which was known as the joint stock company, where joint stock refers to the assets of the company. Corporations' origin goes back to the Sixteenth century and were probably initially found in Italy (Nyazee, 2016, p. 92). In the beginning, establishment of such companies was not an easy task since it required a special legislation by a Royal Decree, accordingly, people started to open companies without taking the permission which led to a number of financial disasters like the bubble companies until the state interfered by passing the Bubble Company Act in 1720. Following this, in 1825, another law was passed that permits the transfer of shares from one person to another, and in the following year, 1826, 
corporations were permitted to sue and be sued under their own name, which gave rise to legal personality concept. Finally, the concept of "limited liability" was acknowledged by the English law in 1844 under the "Limited Liability Act of 1844", and although there was a debate regarding the limited liability form of partnerships in Britain, later on it was accepted (Nyazee, 2016b, p. 365).

Surprisingly, this whole system, which as mentioned was originated and established in England, is borrowed by almost all the Muslim countries today.

In order to cope with the new situation, contemporary Muslim scholars found a need to issue new legislations to help Muslim investors investing and participating in the economic growth, hence the corporation structure and indeed the legal personality concept were accepted and applied, and they have also accepted the structure of banks after being Islamized and called Islamic banks. But some scholars did not agree on the new debt-based system, and this in turn led to differences in opinions and many researchers and writers started to explore new doors to study. Concerning the banking system, there have been three different theories up until today, where each theory is built on different understanding on how money is created and how the banks are functioning. One of the theories, namely the credit creation theory, states that banks are creating money out of nothing and they are the main suppliers of money in the modern time, while the financial intermediation theory for instance states the opposite, i.e. the banks are mere intermediaries and can never create money, and accordingly do not have major effect on the macroeconomic level. These huge differences between the theories drew the attention of many writers and practitioners to find which theory is correct. Moreover, some think that Islamic banks are not different than the conventional banks in terms of the economic substance.

On the other hand, there have been many issues attached to the structure of the modern corporations, the most prevalent one is the legal personality concept, and whether it was acknowledged or even known by the early Muslim scholars "fuqahā". Many Muslim and non-Muslim writers like Alqarradāghī, Nyazee, Sanūsī, Al-Zuhaily, Udovitch, Joseph and others gave this concept great attention and reached similar conclusions except few of them.

Indeed, as the whole structure of corporations was actually copied from the English law which is based on torah and gospel, it has to be very carefully analyzed before being accepted. But unfortunately, it is hard to find literatures analyzing the corporations' structure critically under the principles of Islamic law. Even those researchers who talked about the legal personality issue, they all have used almost the same fragmented approach in concluding their opinions.

\subsection{The Theory and Mechanics of Banking}

The bank lending activities and the money creation process have a tremendous effect on the real economy. A. Bianco and Claudio Sardoni in their study about the effect of banking theories on the macroeconomics stated that failure to incorporate the existing studies of how banks work into the models used in macroeconomics will lead to underestimating the effects of changes in bank lending on the real economy (Bianco \& Sardoni, 2014).

Warner also stated that after the financial crisis of 2007-8, awareness has raised on the role of banking over the whole economy, and that after the crisis the most widely used macroeconomic and financial models proved to be insufficient to describe our economic system features and did not even include banks (Werner, 2014a).

There have been three theories about the banking system, namely, the financial intermediation theory or the "middle man", the fractional reserve theory, and the credit creation theory (Werner, 2014a). The credit creation theory was the prevalent until the mid-to late 1920. Following this was the fractional reserve theory, which dominated the literature until the early 1960s, and was supported by Keynes, Crick, Philips and Samuelson. Finally, up until today, the theory that became dominant and taught in the academic curriculums is the financial intermediation theory (Werner, 2014a, p. 16).

Indeed, there should be only one correct theory. The three theories will be discussed later in detail.

\subsection{The Modern Corporation and Legal Personality}

Corporations have a major role in building the banks' capital as the main source of financing nowadays is based on the corporations' commercial papers, which if not Islamic then the process of capital building itself is not considered legal under the Islamic law.

\subsubsection{The Concept of Modern Corporation}

Modern corporations were actually established as a result of the concept of legal personality. The primary aim of establishing it is perpetuity, so it still exists even if some or one of the shareholders died. Under the American law, "a corporation is a separate legal entity, distinct from its owners, and the owners are not personally liable for 
the obligations of the corporation" (Hillman \& Loewenstein, 2015, p. 100). With regards to the capital structure, the corporation heavily relies on debt financing and are considered a distinct legal entity separate from its owners, so it said to have a separate legal personality (Poulsen, n.d.). This concept caused long debate among the contemporary scholars regarding its permissibility and coherent with the principles of Islamic law. Some of their arguments are discussed in the following sub-section.

\subsubsection{Limited Liability and Legal Personality (Juristic Person)}

There has been a long-standing debate over the legitimacy of the legal personality among contemporary scholars. And it is clear that the majority are keen to prove it for non-human, while some other scholars criticize this opinion. Those who prove it for non-humans rely on some specific contemporary scholars' texts. They claim that bayt al-māl has a separate legal personality and hence the concept is accepted in the Islamic law, others do the same with waqf, while some prove its existence in the property inherited before being distributed to heirs, to schools, orphanages, hospitals, and even to the ummah. Before presenting these opinions, a brief explanation about the concept is needed. What is meant by a separate legal personality or juristic person?

"The juristic person is a presumed person, a legal entity with separate form from the individuals who establish them. It has some human features but not the human qualities. It is a presumed person but not a human being" (Sanusi, 2012, p. 172). According to this concept, a company in itself enjoys the status of a separate entity as distinguished from the individual entities of its shareholders and accordingly can sue and be sued, hold properties under its own name, make contracts, etc (Usmani, 1998, p.154)

But what about the legitimacy of this concept under the Islamic law? The scholars' arguments are summarized below.

Some contemporary scholars find that the two concepts of limited liability and separate legal personality are closely related and if one of them is considered haläl, the other one should also be accepted.

One of these scholars is Muftī Taqi Usmani. He mentioned that the rise of the limited liability was actually simultaneous with the rise of corporations and joint stock companies. He added that in order to decide on the legitimacy of the limited liability under the Islamic law, Muslim scholars need to look at the legitimacy of the legal/juridical personality concept because they are closely related. (Usmani, 1998, p. 152). So, if the non-human was permitted under Shar' 'ah to be treated as a normal person and has its own separate personality, then logically we can apply to it the limited liability concept.

According to Usmani, the definition of limited liability is as follows: "The limited liability' in the modern economic and legal terminology is a condition under which a partner or a shareholder of a business secures himself from bearing a loss greater than the amount he has invested in a company or partnership with limited liability" (Usmani, 1998, p. 152). Accordingly, in case of loss, the maximum a shareholder can incur is only his principal invested from the outset, and creditors will not get compensation in case if the company's assets were not sufficient after being dissolved. John Deweby commented on that issue, by saying, "Not all the legal propositions that are true of a man will be true of a corporation" (Dewey, 1926, p. 656).

Usmani claims that the concept of legal personality is not new to the Islamic law as it's applied to waqf, bayt $a l-m \bar{a} l$, joint stock, inheritance under debt, and under the use of slaves. And he finally concluded that the concept can be used today in public companies only when the company has a considerable number of shareholders who can't be held responsible in day-to-day affairs and losses (i.e. if debts exceeded assets). But it cannot be applied to the partnerships or to private companies where the number of shareholders is limited and hence they should be held responsible for the company's losses and liabilities as they can easily have direct knowledge of the business day-to-day affairs.

Sanūsī also argues that the concept of legal personality or juristic person is recognized by the Islamic law not as many orientalists claim (Sanusi, 2012, p. 171). His opinion was based on almost the same argument used by Usmani and the majority of contemporary scholars. Which is based on the acknowledgement of juristic person to bayt al-māl and waqf. Many other contemporary scholars like Alqarrahdāghī, Muștafā Al-Zarqa, 'AbdulQādir 'Aūdah, 'Abdul' Azīz Al-Khayyāt, AbdulRahīm and others follow similar approaches.

Al-Zuhaily as well claims that the modern corporation is accepted in Islam, as he views the limited liability company by way of 'inān, and hence acknowledges the concept of legal personality (Al-Zuhayli, 2001, p. 530). On the other hand, Nyazee claims that the concept of legal personality was actually existent in the classical scholars' time, but they did not acknowledge it to non-humans, and hence the corporate personality should not be accepted under the Islamic law. He used a prolonged methodology trying to merge all the opinions supporting and legalizing the concept and criticizing them by referring to the original classical texts to which they have 
actually referred in supporting their opinions. A critical analysis of all the opinions will be further elaborated in the findings.

\section{Method}

This is a qualitative research done in relation to three approaches; library research, content analysis as well as case study.

\subsection{Research Design}

In a qualitative research, the researcher's role is to gain a "holistic" (systematic, encompassing, integrated) overview of the context under study: its logic, its arrangements, its explicit and implicit rules (Miles \& Huberman, 1994, p. 6).

According to Yazan, Yin defines the case study as: "a contemporary phenomenon within its real life context, especially when the boundaries between a phenomenon and context are not clear and the researcher has little control over the phenomenon and context" and hence he concludes that Yin views case study as empirical inquiry that investigates the case or cases conforming to the abovementioned definition by addressing the "how" or "why" questions concerning the phenomenon of interest (Yazan, 2015, p. 138). So, case studies are useful in providing answers to 'How?' and 'Why?' questions (Jennifer, 2000, p. 16). This study seeks to clarify how the structure of the current debt-based financial system affects the economic system, how and why it diverges from the principles of Islamic law, and why the equity-based system is more efficient in allocating the investable resources.

According to Merriam (1998), the case can be a person, a program, a specific policy, etc. (Merriam, 1998, p. 27).

Another way used to conduct the current study is analyzing documents. Content analysis such as text or images or similar traces of experiences or interactions is one of the ways used in conducting a qualitative study, (Rapley, 2008). According to Bowen, document analysis is particularly applicable to qualitative case studies - intensive studies producing rich descriptions of a single phenomenon, event, organization, or program, and it involves a systematic procedure for reviewing or evaluating documents (Bowen, 2009, p. 29).

Like other analytical methods in qualitative research, document analysis requires that data be examined and interpreted in order to elicit meaning, gain understanding, and develop empirical knowledge.

\subsection{Research Objectives and Methodology}

The main aim of the underlying study is to find out whether the current financial system comply with the basic principles of Islamic law and whether it succeeded in achieving the Shari'ah objectives (maquassid al-Sharī'ah), and how this system affects the economy as compared to the equity-based system.

For the first objective, the study conducts content analysis and library research in order to investigate the mechanics and structure of modern banking and the provision of debt finance. This has been done by analyzing the empirical study done by Werner (2014) on the three theories of banking and by analyzing some other related studies. The second objective is related to the modern corporation and is considered the core objective of the underlying study. The structure of the modern corporation is re-examined in terms of legal personality as opposed to the mercantile notion of the firm by doing an extensive library research. Moreover, the study yields quotations, texts and selected passages from scholars' books, that have been analyzed and organized through content analysis, such as texts from Al-Zuhaily, Nyazee, Alqarrahdāghī, Sanusi, Udovitch, Al-Sarakhasī, Ibn-Qudāmah, Al-Kāsānī and others in addition to the OIC and AAOIFI. Finally, for the third objective which is to analyze the effect of the two systems on the economy in relation to the MEC, factors pricing and achieving maqāsid al-Sharì'ah, library research as well as case study approaches were adopted. Studies done by Sadeq (1990) and Abdullah (2015) related to the economic impact of equity-based as opposed to debt-based financing and Keynes related theories will be analyzed and elaborated.

\section{Findings and Discussion}

\subsection{The Three Theories of Banking}

Here, the study elaborates more on the three theories of banking mentioned earlier by giving more detail concerning the accounting treatment and other regulatory aspects in order to understand the empirical test done by Werner which will be analyzed in detail in the next sub-section.

According to the financial intermediation theory, the bank is a mere intermediary like any other non-banking institution and is not included in the money creation process. When a customer deposits money with a bank, the deposited amount should not be shown on the liabilities side of the bank's balance sheet, because like any other 
financial intermediary, customers' deposits should be held as custody with the central bank, at least under the UK and major economies. According to Werner, the non-bank financial institutions' balance sheets do not change as a result of a loan extension. Hence, the bank's balance sheet should not lengthen as a result of the loan, because the loan amount will be drawn from the bank's reserve account with the central bank (Werner, 2014a, p. 13).

Briefly, Werner adopted his test by drawing EUR 200,0000 loan from a bank and recording all the accounting records of the bank that day and a day before. Accordingly, in order to analyze this theory under Werner's empirical test, if the bank's balance sheet was changed due to the loan operation or if the customers' deposits were found recorded in the bank's balance sheet then this theory will be disqualified. An example of a balance sheet implications for giving a loan worth $€ 50$ are shown in table 1 .

Table 1. Balance Sheet Implications Under the Financial Intermediation Theory

Before the loan:

\begin{tabular}{cccc}
\hline \multicolumn{2}{c}{ Assets } & \multicolumn{2}{c}{ Liabilities } \\
\hline $\begin{array}{c}\text { Excess Reserves } \\
\text { Total }\end{array}$ & 250 & Equity capital \\
Total & 250 \\
After the loan: & 250 & \multicolumn{2}{c}{ Liabilities } \\
\hline \multicolumn{1}{c}{ Assets } & \multicolumn{3}{c}{ Equity capital } \\
\hline Excess Reserves & 200 & & 250 \\
Loans and Investments & 50 & Total & 250 \\
Total & 250 & & \\
\hline
\end{tabular}

The fractional reserve theory also assumes that the bank acts as a financial intermediary, but regarding the money creation concept, it assumes that the bank is unable to create money individually, but it can do so collectively through systematic interaction when the money is created or multiplied through the so-called money multiplier (Abdullah, 2018b, p. 34).

Under this theory, the bank is supposed to be similar to other financial intermediaries except in one regulatory aspect, which states that the bank's reserves must be held with the central bank, and hence in order for a bank to lend it has to drawdown its reserve balance held with the central bank. Accordingly, before giving a loan, the bank must first receive enough deposits to increase its reserve (Werner, 2014a, pp. 12-13).

"A bank will not lend more than its excess reserves because, by law, it must hold a certain amount of required reserves. ... Each depository institution can create loans (and deposits) only to the extent that it has excess reserves" (Miller \& VanHoose, 1993, p. 331, \& cited by Werner, 2014a, p. 13).

The balance sheet implications of extending a $€ 50$ loan under this theory is shown in table 2 below.

Table 2. Balance Sheet Implications Under the Fractional Reserve Theory

Before the loan:

\begin{tabular}{cccc}
\hline \multicolumn{1}{c}{ Assets } & \multicolumn{2}{c}{ Liabilities } \\
\hline Excess Reserves & 250 & Deposits & 250 \\
Total & 250 & Total & 250 \\
\hline After the loan: & & Liabilities & 250 \\
\hline Assets & 200 & Deposits & \\
\hline Excess Reserves & 50 & & 250 \\
Loans and Investments & 250 & Total & \\
Total & & &
\end{tabular}

The credit creation theory on the other extreme, considers that the bank acts differently from any other intermediary. Under this theory, the bank is actually creating money individually out of nothing, and it does this 
whenever it extends credit. This theory assumes that the bank does not act as an intermediary because it does not have to have enough deposits in order to be able to extend loans. In order for the bank to extend a loan it just creates an entry on the liabilities side of the balance sheet called "customers' deposits" with the loan amount, this entry shows that the bank is liable to pay this amount to the customer sometime in the future, but no actual transfer of money has to be done, and hence according to Werner it is called a "factious customer deposit." Accordingly, the balance sheet should lengthen each time the bank gives a loan. In the empirical test, if the balance sheet remained unchanged after the loan has been extended this theory will also be disqualified. The balance sheet implications of $€ 50$ loan are shown in Table 3.

Table 3. Balance Sheet Implications Under the Credit Creation Theory

Before the loan:

\begin{tabular}{cccc}
\hline \multicolumn{2}{c}{ Assets } & \multicolumn{2}{c}{ Liabilities } \\
\hline Cash Reserves & 250 & Equity Capital & 250 \\
Total & 250 & Total & 250 \\
\hline
\end{tabular}

After the loan:

\begin{tabular}{cccc}
\hline \multicolumn{1}{c}{ Assets } & \multicolumn{2}{c}{ Liabilities } \\
\hline Cash Reserves & 250 & Equity Capital & 250 \\
Loans & 200 & Deposits (borrower's A/C) & 200 \\
Total & 450 & Total \\
\hline $\begin{array}{l}\text { Assets increased, and cash } \\
\text { is not affected }\end{array}$ & $\begin{array}{l}\text { Liabilities increase by adding } \\
\text { the depositor's A/C }\end{array}$ \\
\hline
\end{tabular}

\subsection{The Empirical Test}

According to Werner, it is not possible to decide on the correct theory by depending on theoretical basis without testing them practically and supporting the winning theory with an empirical evidence. And despite the fact that the difference between the three theories actually lies in the accounting treatment found in a bank's balance sheet, none of the previous literatures tried to explain the difference in the accounting treatments under the three theories.

Hence, it was very important to conduct an empirical test that covers the whole accounting process of the loan operation in a bank. Werner made this test by drawing a loan worth $€ 200,000$ from a small cooperative bank in Germany called Raiffeisenbank Wildenberg e.G. on 7 August 2013, and recorded every single step occurring internally on the bank's balance sheet.

By looking at the liabilities side information of the balance sheet, see table 4 , it is revealed by Werner that the bank records the customers' deposits in its balance sheet under the category "claims by customers" and hence considers it as a loan granted by the customer to the bank. So now, the intermediation theory can be disqualified since it states that the bank is considered a mere intermediary like any other non-bank financial institution and hence should keep the customers' deposits off the balance sheet. Again, this theory views the bank as an intermediary that gathers the resources and reallocate them. Another fact that contradicts this theory is found in the assets side of the balance sheet, table 5. The decline in reserves (cash and deposits with other financial institutions) should be equivalent with the increase in the customers' loans since the bank is a mere intermediary and hence lending out the deposits it receives. But this is not the case here, as the reserves have declined by $60,674.69(158,329.86-219,004.55)$, while the claims on customers, i.e. loans increased by $235,071.88(200,000$ $+35,071.88)$, the difference is very high!

So now we are left with the other two theories, namely, the fractional reserve theory and the credit creation theory.

Werner has confirmed that the loan balance of $€ 200,000$ was shown on the same day in his own bank account. On the assets side, we can see Werner's loan very clearly under the "maturity under 4 years", since Werner has confirmed that this is his loan's maturity and luckily there were no other loans given with the same maturity at that day, and this reveals that the increase in liabilities by $€ 189,973.96$ (see table 4 , daily liabilities) was caused 
by Werner's loan; the amount is not exactly the same because indeed there should be some withdrawals done by some of the bank's customers that day. This reveals the fact that the increase in customers' deposits was not a precondition for granting the loan to Werner, and hence this coincides with the fractional reserve theory. This was actually confirmed by the credit department and the directors who confirmed to Werner that none of them have even checked if there is enough reserves or deposits before granting him the loan, see Appendix A.

The credit creation theory of banking is therefore the only theory left that doesn't have any feature contradicting the results of this empirical test. According to this theory, the balance sheet will expand as a result of the loan, the bank opens a factitious account for the borrower in the liabilities side each time it extends a loan, and the bank doesn't need to have enough reserve or deposits before extending credit, as it is actually, not a mere intermediary.

Table 4. Raiffeisenbank Wildenberg e.G.: Daily Accounts' Liabilities. 6 August 2013, 22.46 h. vs. 7 August 2013 , 22.56vh. (in EUR)

\begin{tabular}{lrrr}
\hline Liabilities & \multicolumn{1}{l}{$\begin{array}{l}\text { Balance 6 Aug. } \\
\text { 2013 }\end{array}$} & $\begin{array}{l}\text { Balance 7 Aug. } \\
\text { 2013 }\end{array}$ & Difference \\
\hline 1. Claims by financial inst. & $5,621,456.60$ & $5,621,879.66$ & 423.06 \\
2. Claims by customers & $39,589,177.09$ & $39,759,156.42$ & $169,979.33$ \\
2A. Savings accounts & $10,234,806.01$ & $10,237,118.24$ & 2312.23 \\
2B. Other liabilities & $29,354,371.08$ & $29,522,038.18$ & $167,667.10$ \\
-BA daily & $13,773,925.93$ & $13,963,899.89$ & $189,973.96$ \\
-BB maturity less 4 years & $13,296,042.92$ & $13,273,736.06$ & $-22,306.86$ \\
-BC maturity 4 years or longer & $2,284,402.23$ & $2,284,402.23$ & \\
4. Trust liabilities & 5262.70 & 5262.70 & \\
5. Other liabilities & $12,378.81$ & $12,599.44$ & 220.63 \\
6. Balancing item & $16,996.04$ & $16,996.04$ & \\
7. Reserves & $1,138,497.64$ & $1,138,497.64$ & \\
11. Fund for bank risk & $250,000.00$ & $250,000.00$ & \\
12. Own capital & $3,057,248.57$ & $3,057,248.57$ & \\
13. Sum liabilities & $49,706,136.33$ & $49,884,352.81$ & $178,216.48$ \\
\hline
\end{tabular}

Source: Werner, 2014a, p. 15

Table 5. Raiffeisenbank Wildenberg e.G.: Daily Accounts' Assets. 6 August 2013, 22.46 h. vs. 7 August 2013, 22.56vh. (in EUR)

\begin{tabular}{|c|c|c|c|}
\hline Assets & $\begin{array}{l}\text { Balance } 6 \text { Aug. } \\
2013\end{array}$ & $\begin{array}{l}\text { Balance } 7 \text { Aug. } \\
2013\end{array}$ & Difference \\
\hline $\begin{array}{l}\text { 1. Cash } \\
\text { 2. Bills of exchange }\end{array}$ & 181.703 .03 & 340.032 .89 & 158.329 .86 \\
\hline 3. Claims on financial. inst. & 5.298 .713 .76 & 5.079 .709 .21 & -219.004 .55 \\
\hline 4. Claims on customers & 23.712 .558 .13 & 23.947 .729 .92 & 235.171 .79 \\
\hline -Maturing daily & 932.695 .44 & 967.767 .32 & 35.071 .88 \\
\hline -Maturity under 4 years & $1,689.619 .97$ & $1,889,619.97$ & 200.000 .00 \\
\hline -Maturity 4 years or longer & $21,090,242.72$ & $21,090,342.72$ & 100.00 \\
\hline $\begin{array}{l}\text { 5. Bonds, bills, debt instr. } \\
\text { 6. Stocks and shares }\end{array}$ & $19.178,065.00$ & $19.178,065.00$ & \\
\hline $\begin{array}{l}\text { 7. Stake holdings } \\
\text { 8. Stakes in related firms }\end{array}$ & 397.768 .68 & 397.768 .68 & \\
\hline $\begin{array}{l}\text { 9. Trust assets } \\
\text { 10. Compensation claims on the } \\
\text { public sector }\end{array}$ & 5262.69 & 5262.69 & \\
\hline 11. Immaterial assets & 102.00 & 102.00 & \\
\hline $\begin{array}{l}\text { 12. Fixed assets } \\
\text { 13. Called but not deployed capital }\end{array}$ & 221.549 .46 & 221.549 .46 & \\
\hline 14. Other assets & 707.569 .26 & $711,288.64$ & 3719.38 \\
\hline 15. Balancing item & 2844.32 & 2844.32 & \\
\hline 16. Sum of assets & $49,706,136.33$ & $49,884,352.81$ & $178,216.48$ \\
\hline
\end{tabular}

Source: Werner, 2014a, p. 15

In short, the key function of the banking system in the real world is the provision of debt financing; the creation of new monetary purchasing power through loans (Bianco \& Sardoni, 2014).

According to Werner, what makes the banks special than the other financial institutions is their ability to keep customers' deposits on their balance sheets, i.e. they are exempted from the Client Money Rules that require all firms that hold client money to segregate them in accounts that keep them separate from the assets or liabilities 
of the firm itself, and hence by being exempted from this rule the bank becomes the ultimate legal owner of the money while the depositors are considered mere creditors to the bank. (Werner, 2014b, p. 75)

According to Abdullah, in Islamic banks, in practice the borrower first arranges financing to purchase an asset, and the seller or developer opens an account with the bank and the bank will consider that asset as collateral until the installments have been paid by the borrower in full. Accordingly, in terms of the economic substance and the final result, both Islamic and conventional banks are exactly the same. Since the Islamic financial institutions do not have inventory so they are not considered traders. What they actually do is just structuring and arranging the contracts to simultaneously buy and sell the asset on credit, so that the asset account will be offset with a contra asset account for the repayment of the installments and they will ultimately be left with debit borrower's account and credit seller's account (Abdullah, 2018b, pp. 36-37).

Concludingly, what is called financing under the Islamic banks ended up giving the same result as lending under their conventional counterparts!

Wahāb, the former CEO of bank Mu'amalāt states that upon the completion of the sale contract, the Islamic bank position becomes exactly the same as the conventional bank. They further transfer the whole risk to the client by using the contract of muräbahah, furthermore, by using tawarruq they can actually make any non-Islamic contract Islamic (Wahāb, 2018).

The empirical test explained above is very important in proving the correct theory, but it even reveals a simpler and a very important fact; which is that the accounting treatment is in itself an empirical evidence that banks are creating money out of nothing. Whenever we look at any single product of a bank now, we will find, debit borrower's account, credit depositor's account, which as explained above, proved the credit creation theory.

The test done by Werner was confirmed by the Bank of England as the pioneer model for all fractional reserve banks.

\subsection{The Economic Implications}

It was shown that the credit creation theory of baking considers that there is no one authority having the ability to control the amount of loans extended by banks; i.e. it is not merely the monetary policy of the central bank that affects the level of interest rates in the economy as we have been taught under the fractional reserve theory, accordingly, controlling the amount of money created to the economy is not as easy as expected (McLeay, Radia, \& Thomas, 2014, p. 17). According to the contemporary monetary theories that were accepted by the policy makers, the money supply is either controlled through the interest rates under the Keynesian economic, or through the quantity of money under the neoclassical economic, and in both cases the monetary and price stability were not achieved (Abdullah, 2015, p. 207). Another fact is that due to the double entry bookkeeping system used by banks, every time the bank extends a loan, it will open a new account to the borrower and debit the same amount of the loan to its assets, and consequently new money will be created to the economy, which in turn cause an increase in the purchasing power, but the problem is that this money is actually factitious money; they are just numbers recorded in the customers' accounts, and the true definition of this money should be an obligation of the bank to pay some amount to the customer at some point in the future. Additionally, what makes the problem serious and has a massive effect on the economy is that most money in the modern economy takes the form of bank deposits. In fact, $97 \%$ of the money in circulation today is in the form of bank deposits rather than currency, which are created by the commercial banks themselves (Mcleay, Radia, \& Thomas, 2014, p. 5).

Abdullah concluded that the credit creation ultimately leads to increase in prices in the economy. He stated that "the exponential decline in the value of fiat currencies, as a result of an excessive increase in the supply of money (due to aggregate deposit and loan interest), in relation to demand, the result of which is an exponential increase in prices - the cause is the decline in the value of money, the effect is an increase in prices" (Abdullah, 2018b, p. 39).

So, each time a bank extends credit, it creates money as shown in the empirical test. This leads to an increase in the money supply in the economy relative to the demand, which in turn causes the money to gradually lose its value. This will finally lead suppliers to increase goods' prices. The effect of increasing prices can be illustrated through the aggregate demand curve shown in Figure 1 below:

As shown in the ADC, an increase in the price level (P) leads to a decrease in the real income $(\mathrm{Y})$. Other consequences of higher prices can be as follows: The increase in prices can

- Lead to a decrease in the real values of the nominal assets (IOU), like stocks and bonds

- Reduce the consumption rate relative to the current income, because consumers are now trying to save 
more to rebuild the purchasing power of their wealth

- $\quad$ Reduce the purchasing power of people with fixed or non-increasing income like retirees (Kutasovic \& Fritz, 2017, pp. 141-142)

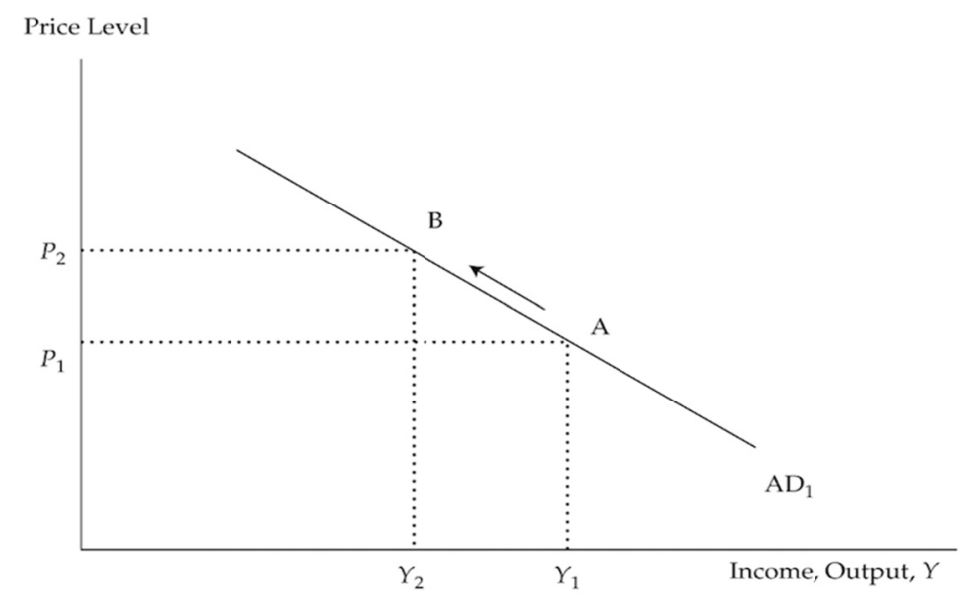

Source: Economics, CFA, 2017, p. 142

Figure 1. The Aggregate Demand Curve

It is clear that one of the main causes for the price increase is the structure of the banking system and their ability to create money through loans. Hence this structure should be re-examined by the researches and practitioners to either suggest a better structure or to find a better alternative to benefit the society and grow the economy. Abdullah suggests that, instead of targeting and controlling the interest rates, the quantity of money supply or inflation, monetary authorities should target a stable value of money, such that prices would remain low and stable by adopting a monetary theory of value (Abdullah, 2015, p. 207).

Moreover, exactly as the bank creates money whenever it extends a loan, it also causes the money to be destroyed after being created in the economy when the depositors withdraw their money from their bank accounts. "Banks making loans and consumers repaying them are the most significant ways in which bank deposits are created and destroyed in the modern economy" (McLeay et al., 2014, p. 17).

\subsection{Impact on Policy and Regulation}

The banking system is actually supposed to lead to financial stability, but currently the opposite is true.

Although many rules and regulations have been established in order to prevent financial crises and to maintain economic and financial stability, we can notice that the financial crises are keep increasing rather than decreasing. The reason is that these regulations were actually built on the idea that banks are intermediaries instead of being the main creators of money supply as shown in the empirical test. Each banking theory gives different policy implications because they are built on different assumptions regarding how money and banks are functioning. Abdullah mentioned that all the following bank regulations were issued in order to maintain financial stability and were built on the basis of the financial intermediation theory: the modern approach to banking theory as reflected in Basel I (1988), which proved to be ineffective in maintaining stability. Also, the capital adequacy-based approach to bank regulation as reflected in Basel I and II which was not successful in preventing major financial crises. Moreover, other approaches to bank regulation are still based on the financial intermediation theory which rise doubt about their suitability, this include Basel III and similar national approaches to bank regulations including related stability measures as reflected in Capital adequacy, Assets, Management capability, Earnings, Liquidity (asset liability management), Sensitivity (to market risk), especially interest rate risk (CAMELS) which was initially introduced in the US in 1979, also, ECB bank stability measures (2013), IMF macro-prudential indicators of financial soundness (2000) and bank stability measure (2009). Furthermore, the IFSB measures of Prudential and Structural Islamic Financial Indicators (PSIFIs).

According to Abdullah, there have been 425 instances of monetary, debt and financial crises sine 1970 up to date despite all these regulations (Abdullah, 2018b, p. 38).

So, it seems odd how the regulators continue working based on the same theory! 


\subsection{Juristic Person}

This issue has been explained in the literature review, and here a deeper elaboration will be conducted by analyzing the contemporary scholars' opinions and comparing them with the original classical texts they relied on while establishing their views in order to clarify whether these opinions are reliable or further questions need to be raised.

Starting with Sanūsī, he is arguing that the concept of legal personality is accepted under the Islamic law by making analogy to waqf and bayt al-māl. He claims that waqf, bayt al-māl and many other institutions have separate legal personality. Moreover, he argues that although the term was not mentioned in the classical fiqh texts explicitly, the concept was actually intended. And that almost all Muslim countries have already drafted their legislations that legalize this concept, even Muslim countries that depend on Islamic law more than the secular law, including, Saudi Arabia, Oman, Kwuait, UAE and Egypt (Sanusi, 2012, p. 172, 184).

He mentioned that, based on the classical Sharì'ah scholars' texts, the three characteristics that qualify an entity to have a separate legal personality are: to have a perpetual life/ status independent of the natural person, to have legal right and can own a property, and to be responsible for legal obligations and can sue and be sued and borrow.

All the above characteristics in his opinion are found in both waqf and bayt al-māl.

Sanūsī claims that there is consensus among all classical scholars that waqf has a separate entity distinct form its administrator and has separate rights and obligations. His conclusion was based on the following reasonings: the fuqaha ' stated that if a property was purchased by the income of the waqf then it becomes the property of the waqf itself, and also that the mutawali (administrator of the waqf) can ask the judge to borrow money on behalf of the waqf, and this was permitted by the fuqahä'. So that waqf is treated like a normal person who can own property and can carry debts (Sanusi, 2012, p. 176).

He used similar analysis to conclude that the concept of juristic person is also attached to mosques, bayt al-māl, hospitals, universities, orphanages and charitable institutions. He also concluded that the Muslim Ummah is considered a separate legal entity form its head of state. Sanūsī has supported his opinion by referring to some texts used by some of the contemporary scholars, like Muștafā Al-Zarqa and 'AbdulQādir 'Aūdah. Mușțafā Al-Zarqa said the following: "When we referred to the original texts and sources of the Shari'ah, we found in it legal provisions which in substance propounds the concept of juristic person and its legal status. And, also, we found the legal provisions which personify the juristic person with all its principles and characteristics which are attributed to it by the latest (Western) law" (Sanusi, 2012, p. 175).

'AbdulQādir 'Aūdah said: "The Islamic law has, since its dawn, recognized the existence of juristic person. The jurists have discussed the state treasury and waqf as juristic persons. Similarly, they have considered the schools, orphanages, hospitals, etc., as the juristic persons and competent to hold and exercise the rights" (Sanusi, 2012, p. 175).

Based on these arguments, most of the contemporary Muslim scholars have accepted to apply the concept of separate legal personality to commercial companies (Sanusi, 2012, p. 179).

Another contemporary scholar whose opinions are respected and followed by the majority of the Arab countries is 'Alī Muhīy al-Dīn Alqarrahdāghī. He also argues as Sanūsī that bayt al-māl and waqf have a separate legal personality. But he added that even mudārabah constitutes this concept. And this is due to many reasons, one of them is that rabb al-māl can buy from the mudārib part of the mudārabah capital, and this is permitted under Hanafis and Mālikis, and this is due to the fact that rabb al-māl has an ultimate ownership (milk raqabah) over mudārabah capital, while the madārib has a managerial ownership over it. So, each one of them is considered ajnabī (stranger) to the mud̄arabah capital from one aspect. From the above Alqarrahdāghi concluded that the ownership of mudāarabah capital has its own privacy, and that the dhimmah of rabb al-māl is separate than the dhimmah of the mudārabah capital, and also the dhimmah of the mudārib is distinct from the dhimmah of the mudārabah capital, so that the mudārabah capital is considered a third-party capital to both partners. Hence, mud̄ārabah capital has a separate legal personality in Alqarrahdāgh̄̄'s point of view (Alqarrahdāghī, 2016).

AAOIFI also has the following to say about Waqf: "3/4/2 The waqf has a legal personality and financial liability which make it capable of giving and accepting commitment. The legal personality of the waqf is quite separate from the personality of its manager" (AAOIFI, 2015, p. 817).

Furthermore, Al-Zuhaily has seen the limited liability form of partnership as a special form of inān with the additional condition of the possibility to add a silent partner, because, in order to raise capital for this kind requires the partners to contribute directly to the company's capital, and hence each partner is considered a full 
owner of the capital share rather than just a holder of a tradable common share as the case in joint stock companies, where the capital is raised through public offering of tradable shares (Al-Zuhaily, 2001, p. 530).

Many other contemporary scholars insist on these opinions like the ones shown in the literature review.

On the other hand, Nyazee criticizes these opinions and proves that the concept of legal personality is not accepted under Sharī'ah. He said the following: "the jurists were denying legal personality to non-humans, while being fully aware of the concept of artificial personality itself as well as its consequences." He added: "None of these institutions (waqf and bayt al-māl) is acknowledged as a fictitious person by Muslim jurists. In fact, they expressly deny personality to some of them." (Nyazee, 2016a, p. 115)

In order to make a proper analysis, we first need to find the Arabic term used in the Islamic law (fiqh) which is equivalent to the legal personality term used in the English law.

The English term personality as used in law is an attribute that the law confers upon a corpus. That corpus can be human or non-human, and for the latter it's called artificial personality.

On the other hand, the term dhimmah in fiqh is defined as: "a legal attribute by virtue of which a human being becomes eligible for acquiring rights and obligations" (Sadr al-Sharī'ah, al-Tawdīh, vol. 2, 750-51, \& cited by Nyazee, 2016a, p. 109). This definition means that with dhimmah the person becomes eligible for ahlyat $a l$-wujūb (capacity for acquisition of rights); i.e. dhimmah is a basic requirement for ahlyat al-wujüb to exist, but these rights and obligations, in order to be performed and qualify the person to acquire ahlyat al-adā' (capacity for execution), some sort of 'aql (mentality) must exist, and hence the dhimmah together with the 'aql assign "legal personality" to the human being. To sum up, dhimmah together with 'aql are considered the essential conditions for legal capacity and this legal capacity has two types namely, ahlyat al-wujūb and ahlyat al- 'adā'. Similar to dhimmah in fiqh, in order for the law to grant ahlyat al- 'adā' (capacity for execution) to the person, some sort of intellect ( $a q l$ ) need to exist. Hence for a corporation to exist as a separate legal entity, it must be attached to an intellect which can be the board of directors. Hence, we can see the similarities between the two terms (dhimmah and personality) under the two laws.

So, in order to answer our original question, we need to know whether dhimmah can be assigned to non-humans or not, because as mentioned earlier, dhimmah is a basic requirement for legal capacity to exist.

Finally, to answer the question above about dhimmah, the following texts of Hanafi scholars should be revised.

Al-Sarakhasī says in his book Usūl al-Sarakhasī: "the rule for this capacity (ahlyah) is not established except after the existence of a sound dhimmah (personality) so that it becomes the location for obligations, and the location is the dhimmah. It is for this reason that the ahkām are associated with it and not with anything else under any circumstances. And it is also for this reason that it is only specific to a human being to the exclusion of all other animals, who do not have a sound dhimmah (personality)" (Al-Sarkhasi, 1097, Vol. 2, p. 333, also cited by Nyazee, 2016a, p. 112).

Al-Ghazālī says: "As for the capacity for the proof of ahkām against the dhimmah (personality), it is available through insāniyah (being a natural person), because of which the human being is prepared for the potential acceptance of ' $a q l$ (intellect), and as a consequence of which the nature of obligation (takliff) is understood. Insofar as an animal does not have the ability to understand the khitâab, either in fact or potentially, it is not prepared for the assignment of a hukm to its dhimmah, and this condition must actually exist or be possibly expected to exist so as to enable us to say that it does exist potentially" (Nyazee, 2016a, p. 111).

Finally, following is the most detailed text cited by Nyazee from Sa'ad Al-Dīn Al-Taftazān̄ form his book Al-Talwīh 'alā Al-Tawdīh: "the intellect is merely to understand the khitāb, while obligation is based upon an attribute that is called the dhimmah (personality), so much so that if the existence of 'aql is assumed without this attribute, like the mounting of intellect on to an animal other than a human, no obligation for or against can be established."

From the above, it should be noticed that what the scholars are trying to reach is that full or workable personality (dhimmah) cannot be assigned to animals, they only acknowledge some sort of unsound personality to them because they don't have the faculty of understanding and this is assigned only to humans. Accordingly, the most important conclusion regarding dhimmah is that all the classical scholars by ijmā' refused to assign dhimmah (legal personality) to non-humans! So how can dhimmah be attached to waqf or bayt al māl or any other thing? According to Nyazee, Hanafi scholars have explicitly denied dhimmah for waqf and bayt al-māl. Most of the scholars who legitimate legal personality to non-humans like Al-qarrahdāghī, Sanūsī and others rely on passages quoted by 'Abdul'Azīz Al-Khayyāt, and when assigning legal personality to waqf they relied on the following passage quoted by him in his book Tanqīh al-Fatāwā al-Hāmidiyah: "Therefore, it is permitted to the nāzir of 
the waqf to raise credit for it and hire for it and to purchase on credit what it needs. What he has raised on credit and what is owed as wages is a debt that is to be satisfied from the ghallah. The property of the waqf is to be rented out and the wages are a debt owed to the waqf, as a liability of one hiring them, and are not to be considered a debt owed to the nazzir or to the beneficiaries. Even when the executor rises credit and is then removed, he is not to be sued for the debt, and the debt is to be satisfied from the ghallah of the waqf, and this is performed by the new näzir. The debtors can't sue the outgoing executor if the new official refuses to satisfy the claims; rather they sue the new executor."

Nyazee argues that Al-Khayyāt relied on ibn 'Ābidīn on stating that opinion, and actually ibn 'Ābidīn himself stated very clearly that waqf doesn't have a legal personality. He said: “...As for waqf, it has no dhimmah (personality). The fuqarā' (poor) do have legal personalities, but the muțălabah (claim) is not possible due to their vast number. Thus, the debt is not established except against the official" (Ibn 'Ābidīn, Hāāshiyah, vol.4, p. $439, \&$ cited by Nyazee, 2016a, p. 121).

What Nyazee is trying to reach from this statement is that the debt actually belongs to the beneficiaries (poor) and this is the truth under the light of the liability principle of the Islamic law (al-kharāj bi al-damān); the principle of liability states that entitlement to profit (revenue) is based on a corresponding liability of bearing loss. Accordingly, in the case of waqf, poor are taking profit and bearing liability of wage payments as all waqf money is considered theirs.

Finally, Nyazee had two objections against the statement of Al-Khayyāt and claimed that it breaks some of the Hanafis rulings. The first objection is that rent actually belongs to the poor (beneficiaries) and this what satisfies the principle of liability as mentioned above, and the second is that in the Hanafi school, agent is always the one who undertakes the performance, and in the case of waqf it is the näzir who must always undertake the contract, and this in order to satisfy the Hanafite role that puts a distinction between $h u k m$ and huqūq.

Another contemporary scholar called AbdulRahīm claims that some Hanafi scholars were inclined to assign personality to waqf, but the statement of ibn 'Ābidēn clearly vanishes this opinion (Nyazee, 2016a, p. 96).

After the above discussion, the study suggests that the majority of contemporary scholars who assign legal personality to non-humans are relying on fragmented texts, while ignoring other classical scholars' texts that are very clearly contradicting and vanishing their opinions. While on the other hand, the criticisms done by Nyazee proved to be correct due to the strong evidences he used.

If the scholars are doing this intentionally, so they must be trying to reach a model like the corporation in order to reduce costs and facilitate transactions. This is a good initiative, but we must try to reach such result without breaking any principle stated in the Islamic law.

\subsection{Mercantile Notion of the Firm}

Some scholars claim that mufāwadah partnership has a legal personality, while others deny this. Abraham L. Udovitch, stated in his book that mufäwadah is considered very close to the modern corporate entity and he depended on the following statement of Al-Kāsānī: "they are in reality two persons, but from the standpoint of principles of commerce, they are like a single person."

Udovitch added: "if we were to substitute the word law for the word commerce in this statement, it would constitute a fairly accurate and acceptable definition of a corporation" (Udovitch, 1970, pp. 113-114).

S.M. Ḥassanuzzamān also follows this opinion and claims that mufāwadah has legal personality and he attributes this opinion to the Hanafi jurist Al-Sarakhasī (Nyazee, 2016b, p. 72).

Further, the Financial Accounting Standards Board (FASB) of the Financial Accounting Organization for Islamic Banks and Financial Institutions also claim that figh has extended the concept of fictitious person (legal personality) to financial institutions including Islamic banks.

Nyazee claims that they have confused the accounting and mercantile notions of the firm with the concept of legal personality. Regarding Hassanuzzaman, Nyazee has cited Al-Sarakhasī's original text that he relied on while establishing his opinion to show that Al-Sarakhasī was not referring to the legal personality. Al-Sarakhasī said: "if two partners in "inān have a claim for a debt on an individual, and one of them agrees to postpone it, the other partner is not bound by this, as against two partners in a mufäwadah. Because the participants to a mufāwadah, insofar as this is a practice of traders, are like a single individual. Postponement of claims is also a practice of traders. Thus, the act of one is like the act of the other. In the "inān partnership on the other hand, they are not treated like a single individual..."

Instead, Al-Sarakhasī was referring to the mercantile notion of the firm which means that partners under a 
partnership that involves the contract of kafālah are treated as one individual according to ahkām (rulings), but they are legally separate. This is actually what Al-Kāsānī meant when he stated the following:

"the act of one of them in this partnership (mufāwadah) is like the act of both, and the statement of one of them is like their joint statement. They are in fact (legally) two persons, but in the ahkām rules of trade they are one individual"

To summarize, in the past, traders and their accountants used to view partnerships and any other collaboration of businesses as a single individual in order to facilitate the accounting recording for these businesses, but the law never granted partnerships a legal personality! So clearly, this is the mercantile or the accounting notion of the firm that the classical scholars were referring to and not the legal personality!

\subsection{Corporations and the Principles of Islamic Law}

Although in the English law a distinction is made between corporation and partnerships in the terminology, in the Arab law, the term sharikah is used for both.

This leads to confusion, as partnership is a contract and its main element is the offer and acceptance. Moreover, partners under partnership are fully liable and hence partnerships should not have separate legal personality.

Some scholars have written about this issue. One of them is 'İsā 'Abduh who said: "As long as the sharikah is a type of bilateral contract that is binding on the contracting parties, is it proper to view subscription to shares and the formation of the sharikatt as a type of (the regular) sharikah in terms of the technical meaning assigned to it? ... in response to this query it is pertinent to point out that the corporation (musāhamah) from the very first moment of its existence does not fulfil the conditions of a contract of sharikah ... therefore, the opinion that musāhamah is a financial institution (nidhām māll $)$, and a venture that adopts this form is considered an organization and not a sharikah, is closer to the truth. The mistake that is widespread in all the laws is that they designate the foremost type of financial institution as sharikah musāhamah" (Isā Abduh, al-Uqūd al-Shar'iyah al-Hakīmah, pp. 36-37, \& cited by Nyazee, 2016a).

So, the writer means that the term sharikah should not be used for corporations and it should be replaced by the term financial institution or nidhām māle in Arabic. According to Nyazee, the word sharikah as used in the Islamic law has two meanings: mixing of shares, and the contract between the partners. When in the Arab law they used the term sharikah for corporations as well as for partnerships, they by virtue considered the corporation to be a contract. For this regard, the following questions should be raised: as long as the corporation is a contract so who are the contracting parties and what is the nature of that contract? what is the kind of the relationship between the shareholders and the corporation, i.e. what is the contract of authority? Does this relationship satisfy the principles of the Islamic law of contract?

In fact, the Islamic Fiqh Academy (OIC) issued resolutions in 1992 that considers corporation as a contract by using the term sharikah and considering the undivided share in the assets of the sharikah as the subject matter. Some relevant statements under the OIC Resolution No. 7/1/65 are listed below:

\section{Shares in Sharikāt}

As the original rule in mu'amalāt is permissibility, the formation of a sharikāt musāhamah having lawful objectives and activities is valid.

\section{Shares with Respect to Their Bearer}

The mabaī' (property sold) in the shares with respect to the bearer of the shares is an undivided share in the capital of the sharikah, and the share certificate is the instrument that is proof of this right in the share. There is, therefore, no shar' $\bar{\imath}$ obstacle to the issuance of shares in this way and to transactions in them.

3. The Subject-matter of the Contract in the Sale of the Shares

The subject matter of the contract in the sale of shares is the undivided share in the assets of the sharikah. The share certificate is the instrument of the right to this share (Majallat Majma' al-Fiqh al-Islamī, \& cited by Nyazee, 2016a, pp. 146-147)

According to Nyazee they have most probably depended on the contemporary scholar's opinion, Alqarradāghī for these resolutions. Alqarradāghī said: "the division of the capital of the sharikah into shares and parts, and the stipulation of the prior conditions, are not opposed to the general principles of the Islamic Shari' $a h$, nor the general principles of the Sharì' 'ah in Islamic fiqh" (Alqarradāghī, al-Aswāq al-Mālīyah, p. 87, \& cited by Nyazee, 2016a, p. 149). He also said: "the sale of an undivided joint share in property (i.e. sharikat al-milk) is permitted by the agreement of the jurists" (Nyazee, 2016a, p. 151). 
Nyazee has criticized these resolutions. He stated that despite that these scholars and the OIC academy have permitted the concept of legal personality, they actually failed to analyze the corporation on the basis of that concept. His reasoning is that if the corporation has a separate legal personality, this means that all the capital and paid-up shares and title are actually owned by it. How come in the same time the contemporary scholars are applying the roles of partnerships and co-ownerships to the corporation? What they did according to him is that they validated the juristic person concept under the Islamic law, and then ignored its existence in the legal analysis. He said: “ $\ldots$ in the treatment of the share certificate as evidence of an undivided share of the shareholder in the assets of the business, the corporation as a legal person has no role to play. The laws of partnership (sharikah) are applied to resolve the issues" (Nyazee, 2016a, pp. 153-154).

This criticism seems very logical, because in partnerships, the capital which is the subject matter of the contract should be owned by the partners. While in the corporation, the whole capital is owned by the corporation itself and not by the shareholders. Actually, shareholders and their certificates have no direct relationship with the assets of the corporation. How come then they apply the roles of the partnerships and co-ownerships to corporations with the existence of the legal personality concept? This seems to be very contradictory!

Another criticism made by Nyazee is that they used the principle if $i b \bar{a} h a h$ to legitimate the corporation, while it's not a basic principle, and ignored the principles of $r i b \bar{a}$ and liability while they are basic principles!

Table 6 below makes a comparison between the two main forms of partnerships, mudārabah and mushārakah, and the corporations from different aspects to help examining the principles.

Table 6. Relationship between Partners in Muḍarabah and Mushārakah Vs. Relationship Between Corporation and Shareholders

\begin{tabular}{|c|c|c|c|}
\hline & Muḍārabah & Mushārakah & Corporation \\
\hline Offeror & Capital provider ( $r a b b a l-m \bar{a} l)$ & Partners & Shareholders (the initial members) \\
\hline Acceptor & Entrepreneur (muḍārib) & Partners & No acceptors \\
\hline $\begin{array}{l}\text { Subject } \\
\text { Matter }\end{array}$ & $\begin{array}{l}\text { Contributed Capital by rabb } \\
a l-m \bar{a} l\end{array}$ & $\begin{array}{l}\text { Wealth under sharikat al-amwāl } \\
\text { Credit-worthiness under sharikat } \\
\text { al-wujūh } \\
\text { Labor/work under sharikat al-abdān }\end{array}$ & Paid-up Capital \\
\hline $\begin{array}{l}\text { Wakälah } \\
\text { (Agency) } \\
\text { And } \\
\text { Kafälah } \\
\text { (Surety) }\end{array}$ & $\begin{array}{l}\text { Entrepreneur (can buy and sell } \\
\text { on credit on behalf of the } \\
\text { capital provider), but cannot } \\
\text { exceed the limit of the capital }\end{array}$ & $\begin{array}{l}\text { In: } \\
\text { 'Inān: each partner is wakīl to the } \\
\text { other (with limited liability) } \\
\text { Mufāwadah: each partner is wakill and } \\
\text { kafil to the other (full liability) }\end{array}$ & $\begin{array}{l}\text { The appointed office by the } \\
\text { company, and has the right to buy } \\
\text { and sell on credit with no limit }\end{array}$ \\
\hline $\begin{array}{l}\text { Amānah } \\
\text { (Trust) }\end{array}$ & $\begin{array}{l}\text { Muda ârib is the amin (rabb } \\
\text { al-māl is the sole and ultimate } \\
\text { owner of the capital) }\end{array}$ & All partners are amin under all forms. & $\begin{array}{l}\text { No amin (corporations became the } \\
\text { sole owner) }\end{array}$ \\
\hline Liability & Capital provider (fully liable) & All partners are fully liable & Shareholders are not liable \\
\hline Profit & $\begin{array}{l}\text { Shared according to a } \\
\text { pre-determined rate }\end{array}$ & $\begin{array}{l}\text { Shared according to a pre-determined } \\
\text { rate }\end{array}$ & $\begin{array}{l}\text { Only to shareholder } \\
\text { Corporation only takes the } \\
\text { incurred expenses for making the } \\
\text { profit }\end{array}$ \\
\hline Loss & $\begin{array}{l}\text { Rabb al-māl losses his capital. } \\
\text { Muḍārib losses his time and } \\
\text { efforts. }\end{array}$ & $\begin{array}{l}\text { All partners carry up the loss in } \\
\text { proportion to their share }\end{array}$ & $\begin{array}{l}\text { Creditors first in line before } \\
\text { shareholders } \\
\text { Corporation goes bankrupt }\end{array}$ \\
\hline
\end{tabular}

Source: Abdelkader, 2019, p. 79

Starting with offer and acceptance, rukn al-ījāb wa al-qubūl, we can find that both mudārabah and mushārakah have offerors and acceptors and hence satisfy the principle. In the case of mudarabah the partner providing capital ( $r a b b a l-m \bar{a} l)$ is the one who offers and the entrepreneur (mud̄arib) accepts the offer. Mushärakah on the other hand is of different forms, and in each form all partners participate in the subject matter that can be wealth, labor or credit worthiness. From the outset of mushärakah, all partners agree about the contribution of each partner and offerors who can be contributors also agree with the offerors about the type and amount of business. So, the principle of offer and acceptance is also clearly satisfied in the case of musharakah. Moving to the modern corporation, we find that there are offerors but no acceptors! In the very beginning, when the initial 
shareholders (promoters) apply for the memorandum of association from the securities commission Malaysia for example in case if the company was based in Malaysia, they will need to specify who are the initial shareholders (i.e. the promoters), how much is the paid-up capital, they will have to appoint the directors, etc. Upon this, they will be given the certificate of incorporation which affirms that from this moment the corporation has a legal personality, although their company has not yet done any real business, the only thing happened is that the shareholders have agreed to offer or divide up the capital, but who are the acceptors! Frankly, there are no acceptors in the modern corporations and hence clearly it breaks the main principle of offer and acceptance!

The second issue is the principle of liability, rukn al-kahrāj bi al-damān. Under this principle, the return that one gets should be proportional to the risk assumed (Fātin, 2013).

In muda arabah, the offeror ( $r a b b a l-m \bar{a} l$ ) is fully liable for any loss as long as the loss was not due to the mudārib's negligence. And as the mudārib is working solely on the investment without any intervention from rabb al-māl, in case of loss he will lose all his time and efforts unrewarded, and hence both of them satisfied the rukn of al-karāj bi al-damān. In mushārakah, all the partners are fully liable to pay the whole loss according to the ratio of capital share, and hence very clearly satisfied the principle of liability. Udovitch commented on that issue by stating: "In Hanafi law, and indeed in all of Islamic law, the liability in all partnerships is unlimited. In all Islamic partnerships, the partners are liable in proportion to their share of the total investment. There is no limit whatsoever on the amount of the partnership's liability. Each partner is responsible for his share of the partnership's indebtedness regardless of what it amounts to, or by how much it exceeds the value of his own share of the company's assets" (Udovitch, 1970, p. 55).

In fact, all forms of business organizations in Islamic law should have unlimited liability. In corporations on the other hand, shareholders are only liable to pay for any loss only up to their share in the paid-up capital, and this is a consequence of the concept of legal personality attached to corporations. If after dissolving its assets the company still have creditors not yet paid, the company will go bankrupt and the creditors will simply lose their money. So, the principle of liability was not satisfied here as the shareholders actually did not bear any risk, so what makes them eligible for such profits?

Actually, the only loser in the case of loss is the creditor. Posner says: "the alert reader will perceive, however, that limited liability is a means not of eliminating the risks of entrepreneurial failure but of shifting them from individual investors to the voluntary and involuntary creditors of the corporation _ it is they who bear the risk of corporate default. Creditors must be paid to bear this risk" (Posner, Economic Analysis of Law, 1972, p.290, \& cited by Nyazee, 2016a, p. 160).

It is clear from the above that shareholders actually don't have limited liability, instead they have no liability! They are mere creditors sharing profits on the basis of their investments. They are actually claim on the assets of the corporation after the third parties, because the assets belong to the corporation not to them.

After saying this, we can refer again to Al-Zuhaily's opinion. He said the following about the limited liability company: “... the company is very similar to associations of capital. On the other hand, the company is also similar to associations of individuals since each partner is a full owner of a capital share rather than a holder of a tradable common shares... This type of company is also permissible as a special form of rein (limited) partnerships with the possibility of adding a silent partnership component" (Al-Zuhaily, 2001, p. 530).

It seems strange how Al-Zuhaily claims that the limited liability company is a type of 'inān while there are no acceptors only offerors and hence it does not satisfy the rukn of offer and acceptance! It does not even satisfy the principle of liability. In fact, the difference between limited liability company and inān partnership is considerable and very clear.

It has been further elaborated by Nyazee in his book about partnerships that the only distinction to be made in case of 'inān and mufāwadah is that the liability under mufäwadah is always joint, while under 'inān it is joint only when kafälah contract is attached with wakälah (Nyazee, 2016a, p. 196).

It should also be noted that a defect in rukn like offer and acceptance for instance, makes the contract void/bătill, i.e. cannot be amended and has to be repeated (Hasan, 2017, pp. 4-5).

Other issues are related to the contracts that form partnerships and corporations. As mentioned earlier, the partnership is made up of some contracts that govern the relationship between the partners, and each combination gives rise to a different form. Mufäwadah for instance contains both the contract of wakälah and kafälah together, so that each partner is fully liable for any act done by any other partner, while in 'inān, it is generally based on wakälah, which gives partners limited authority towards each other's actions. What is the case then under the modern corporation? What kind of contract exists between shareholders (promoters or 
subscribers) and corporation?

As per the contract that govern the relationship between the promoters and the corporation as considered a separate legal person, the relationship is expected to be governed through the memorandum of association that has been registered by the promoters in the beginning in order to bring this corporation into existence.

Nyazee says about this memorandum: "the corporation created by the promoters has nothing to do with the promoters after it comes into existence. Any initial contract that the promoters may have had among themselves is non-existent for the corporation created by their efforts" (Nyazee, 2016a, p. 184).

The English law also denies that this memorandum is a contract. Lindley says: "Promoters of companies are not partners; they are, it is true, engaged in a common object, and that object is ultimately to share profits, but their immediate object is the formation of a company, and they are only in the position of persons who intend to become partners after the company is formed" (Lindley, 1888, p. 35).

But surprisingly, the Egyptian law, and in turn the Arab law, are considering the memorandum of association to be the initial contract between the promoters and the company.

In fact, this memorandum merely contains the objectives, the place of origin or citizenship of the corporation and the amount of paid up capital. So how can it be considered a contract that govern the relationship between the corporation and promoters?

Regarding the relationship that exists between all the shareholders and the corporation, it is expected to be governed through the contract of wakälah (agency). Wakälah is considered the main principle of contractual partnerships. AAOIFI states the following about wakālah: "The general basis of sharikah is agency (wakālah) because each partner is acting as a principal partner on one hand and acting in the interest of the partnership on the other hand as the agent for the remaining partners" (AAOIFI, 2015, p. 353).

The role of this contract is very clear under both mudāarabah and mushärakah. Under the former, the entrepreneur (mud̄arib) is the wakil (agent) of the capital provider (rabbal-māl), but he can buy and sell on credit only up to the limit of the partnership capital, any extra credit transaction will not be considered part of the mudārabah business. In mushärakah, there can be wakālah only and this is called 'inān, or both wakālah and kafälah can be found in the same partnership, and this is the mufäwadah partnership. So, in the case of mushäraka, each partner is considered a wakīl or a wakīl and a kafil for each of the other partners. On the other extreme, the subscribers in a corporation actually do not even know each other, so it is very clear that they have never exchanged any offer and acceptance before. They have never met. One shareholder can leave the corporation without any permission from the others, actually without even a prior notice. So obviously there is no relationship among them. They are not partners!

Furthermore, the corporation is not the agent of the shareholders. The contract of wakālah is found to be confusing in the case of corporations. In a corporation, shareholders can appoint directors to be their agents, but shareholders can also choose to be the directors, i.e. the management who are authorized to trade. So, in the modern corporation, we have the management, the trade unions (labors), the shareholders, and the creditors, and it is not clear who is the agent for whom, they are actually all fighting instead of participating! And hence the difference is very clear between partnerships and corporations. In the former, the labor is the partner is the management is the agent, and all partners are participating together. While in the latter it is even very difficult to specify who is who.

Accordingly, after discussing the contracts that form the corporation, no contract has been found under which the principles of Islamic law can operate!

These are the most important and related aspects that needed to be discussed in this regard. And based on this discussion, the study found that not only the concept of legal personality or juristic person clashes with the principles of Islamic law, but the whole structure of the corporation actually needs to be questioned and re-examined by the contemporary Muslim scholars.

\subsection{The Marginal Efficiency of Capital and Factors Pricing}

Abdullah argues that the allocation of investable resources is more efficient under Islamic economic system than under the conventional system. And this is clear when the marginal efficiency of capital (MEC) was tested under both systems. Under the conventional economic system which is mainly based on debt, the investor will keep investing until the point where MEC or the rate of return (RoR) is greater than the interest, otherwise, when they are equal, the investor will stop investing because this means he is no more generating any extra profit and is paying whatever he earns as interest. Furthermore, if the interest turned to be greater than the MEC, then the 
investor will be making losses. On the other extreme, as Islam prohibits generating money just out of money (i.e. interest), then the Muslim entrepreneur will continue investing without taking this point into consideration as he is not paying any interest on the invested capital. In other words, the entrepreneur in partnerships can carry out the investment to its fullest potential, i.e. to the level where the marginal efficiency of capital equals zero. This means that Islamic economic system and hence equity-based financing leads to higher investments and in turn higher employment. This goes in line with Keynes statements about interest, he said: "interest holds back investment in production" (Keynes, 1936, p. 235), and "interest sets a limit to the level of employment due to the reduced marginal efficiency of interest-based capital" (Keynes, 1936, p. 222).

Another difference between partnerships and the debt-based system is the pricing of labor, under the Islamic economic system, which is mainly based on equity, there are some principles that must be followed in factor pricing, which are not existent in the conventional system, that depends mainly on debt. These principles are justice, scarcity and humanity in labor pricing (Sadeq, 1990, p. 44).

Sadeq states that in an Islamic economy, and hence in equity-based system, labor is not treated as a saleable material commodity, as labor is always attributable to mankind. By humanity principle Sadeq meant the following: the employer should deal with his employee in a man-to-man brotherly relationship, and not like a man-to-material relationship, the workload should be humanely acceptable, and the employer should provide the employee with the basic needs like food and clothes. So all these aspects together with justice and following them the market forces, i.e. scarcity, will determine the price of labor, i.e. wages (Sadeq, 1990, p. 46).

While on the other hand, according to Abdullah, in an interest-based system the main aim is profit maximization. In that system a firm can substitute two different factors of production in order to produce the same level of output and minimizing the cost using the so-called production isoquant. These factors are labor and capital (Abdullah, 2015, pp. 33-35). So, it is clear that in an interest-based system, the humanity principle is not existent, and labors are treated as a mere commodity.

\subsection{Relating the Discussion to Maqāșid Al-Sharī'ah}

As was proved by the empirical test done by Werner, banks either Islamic or conventional are not working as intermediaries that facilitate the flow of funds in the economy and accordingly grow the economy, they are instead creating money whenever they extend credit, and this proved to be negatively affecting the whole economy by creating a fictitious purchasing power _which is considered fraud!_ and finally increase the prices leading to restricting investments and increasing unemployment. Accordingly, the objective of protecting wealth was clearly not met under the current financial system. Indeed, affecting one objective will not stop at this point, but will affect the other objectives as well. For instance, protecting self, intellect and lineage cannot be obtained if wealth was not protected (Ali, n.d., p. 6).

Frankly, Islamic banks basically work exactly the same way as conventional banks in the process of loan extension, the only difference is that Islamic banks have to structure some Islamic contracts in the middle in order for the process to be or, to look Islamic, Abdullah said: "They structure risk-bearing sales contracts and arrange them, as a stratagem, into risk-free debt contracts at the TVM (Time Value of Money). This enables IFI's to increase their assets and balance sheet by financing (loan) amount, such that they create money out of nothing (i.e. they create fictitious purchasing power)" (Abdullah, 2018b, p. 37). According to Wahāb, upon the completion of the sale contract, the Islamic bank position becomes exactly the same as the conventional bank. They further transfer the whole risk to the client by using the contract of murābahah, furthermore, by using tawarruq they can actually make any non-Islamic contract Islamic. (Wahāb, 2018)

Another problem with the whole Islamic financial system today, either banks or corporations, is that focus is given to the legal form of contracts, while ignoring two things, the ultimate effect of the whole operation and the achievement of maqāsșid al-Sharì'ah.

One example is the structure of the mudārabah contract in banks today. Because Islamic economic system aims to encourage all classes to invest and participate in the economic cycle, mudāarabah was an available option. Under mudārabah the poor has an opportunity to employ his skills without participating in the mudārabah capital and without even bearing any financial losses, and this is the best application of justice in an economy, because Islamic economic system doesn't value money only as the secular system, but it also values the efforts done by the partners, and in the case of a loss the mudatarib will lose all his efforts unrewarded. Surprisingly, banks today are acting the role of mudārib instead of being rabb al-māl! (Nyazee, 1995, p. 156)

The bank, that has billions of customers' deposits, acts the role of the poor and collects money from customers and in case of a loss the customer will bear the loss! How does this encourage justice in allocating the investable 
resources? And how does this add to the growth of the economy? In fact, by doing this the banks have ignored the original purpose behind the mudārabah contract and did not achieve the intended objectives of Sharì'ah.

Islamic banks' modes of finance are actually satisfying the legal form, but in terms of the economic substance, they are replicating debt-based financing at the time value of money. Abdullah mentioned some real examples elaborating this point including the case of muräbahah _ which is the most widely used mode of financing in the Islamic banking industry _ when it was first introduced to the U.S., the OCC (Office of the Controller of the Currency) said that the murābahah financing is functionally equivalent to the conventional financing, and that under muräbahah the Islamic bank will be acting as a riskless principal (OCC, 1997, p. 15, \& cited by Abdullah, 2015, p.58-59). Also, the OCC said the following about the ijärah wa-iqtinā' mode of financing: "...Here it is clear that ijärah wa iqtin $\bar{a}$ ' is functionally equivalent to a financing transaction in which the branch occupies the position of a secured lender..." (OCC, 1997, p. 15, \& cited by Abdullah, 2015).

\section{Conclusion}

It is surprising how the financial intermediation theory is still prevalent, even though it is very clear that banks are the main source of money supply and they are creating money out of the thin air. This have been proved by elaborating on the accounting treatment of the process of loan extension through the empirical test done by Werner. And it has been proved that Islamic banks did not succeed in achieving maqāssid al-Sharī'ah due to the fact that they are not any different than the conventional counterparts.

The structure of the corporation has been thoroughly examined, and the main conclusion was that the concept of juristic person was actually well-known by our classical scholars, but they denied it to non-humans. This was proved by analyzing and comparing numerous texts written by contemporary and classical scholars. Another important conclusion related to the corporations was that although the concept of juristic person is the most important issue that needs to be re-examined by the contemporary scholars, other major issues related to the structure itself also need to be re-examined as there proved to be many contradictions between the structure of the corporation and the principles of Islamic law.

Basically, debt-based financing proved to be a non-efficient way in allocating the investable resources or even in pricing the factors of production. When we compare this to the equity-based financing; partnerships, we can find huge differences in the results concerning many aspects like investment and employment. This have been proved through studies made by Sadeq and Abdullah.

Although partnerships have proved to be more efficient in terms of allocating the investable resources, spreading justice, achieving maqāșid al-Sharì'ah, and in many different aspects shown in the current section, why still there is a silence on implementing it in today's system and turn back to equity-based financing?

\section{References}

AAOIFI. (2015). Shari'ah Standards. Dar AlMaiman for Publishing \& Distributing. Retrieved from http://www.iefpedia.com/english/wp-content/uploads/2017/12/Shariaa-Standards-ENG.pdf

Abdelkader, S. (2019). Re-Examining the Structure of Firms and the Provision of Finance/ the Case for Islamic Partnerships. Institute of Islamic Banking and Finance (IIiBF). International Islamic University Malaysia.

Abdullah, A. (2015). Economic Security Requires Monetary and Price Stability: Analysis of Malaysian Macroeconomic and Credit Data. Al-Shajarah, 20(Specialissue), 205-247. Retrieved from https://www.scopus.com/inward/record.uri?eid=2-s2.0-84982886745\&partnerID=40\&md5=ce57b19fabf1 1 f53205021f565f $2 \mathrm{~b} 0 \mathrm{fd}$

Abdullah, A. (2015). Fundamentals of Islamic Economics. International Council of Islamic Finance Educators (Icife).

Abdullah, A. (2018). Money and The Real Economy: From an Islamic Perspective. IIUM Institute of Islamic Banking and Finance (IIiBF).

Al-Zuhaily, W. (2001). Financial Transactions in Islamic Jurisprudence (Vol. 1). Dāar Al-Fikr, Damascus.

Ali, A. (n.d.). Necessities, Conveniences and Refinements (Al-Ḍarūriyyāt Wa Al-Ḥājiyyāt Wa Al-Taḥsīniyyāt). Supreme Council for Islamic Affairs. Retrieved from http://www.imtithal.com/uploaded/media/research/ 70413.pdf

Alqarrahdāghī, A. (2016). The Legal Personality and Its Provisions in the Modern Country and its Effects on the Implementation of the Ultimate Ownership Principle (Al-Shakhṣyah Al-I'tibāryah Wa Aḥkāmuhā F̄̄ Al-Dawlah Al-Mu'āṣirah Wa Āthāruhā F̄̄ Tạ̣qīq Sharț Al-Milk Al-Tām). Retrieved from 
http://www.qaradaghi.com/chapterDetails.aspx?ID $=492$

Bianco, A., \& Sardoni, C. (2014). Banking Theories and Macroeconomics. Sapienza University of Rome. Retrieved from https://www.boeckler.de/pdf/v_2016_10_21_sardoni.pdf

Bowen, G. A. (2009). Document Analysis as a Qualitative Research Method. Qualitative Research Journal, 9(2), 27-40. https://doi.org/10.3316/QRJ0902027

Çizakça, M. (1996). A Comparative Evolution of Business Partnerships. E.J. Brill, Leiden. New York. Köln, Vol. 8.

Dewey, J. (1926). The Historic Background of Corporate Legal Personality. Yale Law Journal, 35(6). https://doi.org/10.2307/788782

Fātin, N. (2013). Al Kharāj $B i \quad A l \quad$ Damān. Retrieved from https://www.scribd.com/doc/125629628/Al-Kharaj-Bi-Al-Daman

Hasan, A. (2017). Conditions of Contract. Presentation at IIiBF, IIUM, Kualak Lumpur.

Hillman, R. W., \& Loewenstein, M. J. (2015). Research Handbook on Partnerships, LLCs and Alternative Forms of Business Organizations. Edward Elgar Publishing, Cheltenham, UK. Northampton, MA, USA. https://doi.org/10.4337/9781783474400

Jennifer, R. (2000). Using Case Studies in Research. Management Research News, 16-27. Retrieved from https://pdfs.semanticscholar.org/4e18/426cc8767b4141c924236612aafaef75fa75.pdf

Keynes, J. M. (1936). The General Theory of Employment, Interest, and Money. The Royal Economic Society Basingstoke: Palgrave Macmillan.

Kutasovic, P., \& Fritz, R. (2017). Economics CFA Program Curriculum, Level I, Volume 2. CFA Institute.

Lindley, N. (1888). A Treatise on the Law of Partnership, vol. F.D. LINN \& Co, Law Publishers \& c. Retrieved from https://archive.org/details/treatiseonlawofp01lind/page/n6

Mcleay, M., Radia, A., \& Thomas, R. (2014). Money in the Modern Economy: An Introduction. Bank of England Quarterly Bulletin, 54(1), 4-13. Retrieved from https://www.bankofengland.co.uk/-/media/boe/files/qu arterly-bulletin/2014/money-in-the-modern-economy-an-introduction.pdf?la=en\&hash=E43CDFDBB5A2 3D672F4D09B13DF135E6715EEDAC

McLeay, M., Radia, A., \& Thomas, R. (2014). Money Creation in the Modern Economy, (1), 14-27. Retrieved from https://www.bankofengland.co.uk/-/media/boe/files/quarterly-bulletin/2014/money-creation-in-the-m odern-economy

Merriam, S. B. (1998). Case Study Research in Education: A Qualitative Approach (pp. 26-43). San Francisco: Jossey-Bass. Retrieved from http://www.appstate.edu/ jacksonay/rcoe/merriam.pdf

Miles, M. B., \& Huberman, A. M. (1994). Qualitative Data Analysis.pdf(2nd ed.). Sage Publications. Retrieved from https://vivauniversity.files.wordpress.com/2013/11/milesandhuberman1994.pdf

Nyazee, I. (1995). The Concept of Riba and Islamic Banking. Center for Excellence in Research, Islamabad, Pakistan.

Nyazee, I. (2016a). Islamic Law of Business Organization: Corporations. Center for Excellence in Research, Islamabad.

Nyazee, I. (2016b). Islamic Law of Business Organization: Partnerships. Center for Excellence in Research, Islamabad.

Poulsen, A. (n.d.). Corporate Financial Structure. Retrieved from https://www.econlib.org/library/Enc/ CorporateFinancialStructure.html

Rapley, T. (2008). Doing Conversation, Discourse and Document Analysis. SAGE Publications. https://doi.org/10.4135/9781849208901

Sadeq, A. H. M. (1990). Economic Development in Islam. Pelanduk Publications (M) Sdn. Bhd.

Sanusi, M. M. (2012). Islamic Banking and Finance-Shari'ah and Legal-Issues and Challenges. Aslita Sdn. Bhd.

Udovitch, A. L. (1970). Partnership and Profit in Medieval Islam. Princeton University Press Princeton, New Jersey. https://doi.org/10.1515/9781400820474 
Usmani, M. M. T. (1998). An Introduction to Islamic Finance. Retrieved from https://muftitaqiusmani.com/en/ books/PDF/AnIntroductionToIslamicFinance/An_Introduction_to_Islamic_Finance.pdf

Wahāb, A. (2018). Money and Banking Including Islamic Banking. Presentation at IIiBF, IIUM, Kuala Lumpur.

Werner, R. A. (2014a). Can Banks Individually Create Money Out of Nothing? The Theories and the Empirical Evidence. International Review of Financial Analysis, 36, 1-19. https://doi.org/10.1016/j.irfa.2014.07.015

Werner, R. A. (2014b). How Do Banks Create Money, and Why Can Other Firms Not Do the Same? An Explanation for the Coexistence of Lending and Deposit-Taking. International Review of Financial Analysis, 36(C), 71-77. https://doi.org/10.1016/j.irfa.2014.10.013

Yazan, B. (2015). Three Approaches to Case Study Methods in Education: Yin, Merriam, and Stake. The Qualitative Report, 20(2), 134-152. Retrieved from http://www.nova.edu/ssss/QR/QR20/2/yazan1.pdf

\title{
Appendix A
}

Letter of Confirmation of Facts by Raiffeisenbank Wildenberg e.G.

10 June 2014

\author{
Dear Prof. Dr. Werner, \\ Confirmation of Facts \\ In connection with the extension of credit to you in August $2014 \mathrm{I}$ am \\ pleased to confirm that neither I as director of Raiffeisenbank Wildenberg \\ $\mathrm{eG}$, nor our staff checked either before or during the granting of the loan \\ to you, whether we keep sufficient funds with our central bank, DZ Bank \\ AG, or the Bundesbank. We also did not engage in any such related trans- \\ action, nor did we undertake any transfers or account bookings in order \\ to finance the credit balance in your account. Therefore we did not engage \\ in any checks or transactions in order to provide liquidity. \\ Yours sincerely, \\ M. Rebl, \\ Director, Raiffeisenbank Wildenberg e.G.
}

\section{Copyrights}

Copyright for this article is retained by the author(s), with first publication rights granted to the journal.

This is an open-access article distributed under the terms and conditions of the Creative Commons Attribution license (http://creativecommons.org/licenses/by/4.0/). 